\title{
SALINITY STRESS TOLERANCE OF THREE COWPEA CULTIVARS IN A SOUTHERN GUINEA SAVANNAH ECOLOGICAL ZONE OF NIGERIA
}

\author{
I. KAREEM ${ }^{1}$, A.I. MUSA ${ }^{1}$ \\ *E-mail: abdulkareemishaaq@gmail.com
}

Received: Oct. 11, 2019. Revised: Dec. 13, 2019. Accepted: Dec. 19, 2019. Published online: Dec. 20, 2019

\begin{abstract}
To combat the problem of food scarcity and insecurity in areas affected by salinity, crop varieties that are tolerant to the stressful conditions should be selected and used. Therefore, this study was carried out to investigate and know the effects of salinity stress on growth and yield of three cowpea cultivars to select the best salinity tolerant cultivar for optimum yield production. To achieve this, three separate experiments were concurrently carried out using ITIOK-298-15, IFE BROWN and SAMPEA 11 cowpea cultivars in the glass house of the Faculty of Agriculture, University of Ilorin, Nigeria. The salinity levels tested in each of the cultivars were $0 \mathrm{mM}$ (the control), 50mM, $100 \mathrm{mM}$ and $200 \mathrm{mM}$ sodium chloride $(\mathrm{NaCl})$. The imposition of salinity stress was for a period of two weeks at maturity because this stage is the most sensitive stage for any crop grown under any environmental stress. The experiments were laid out in randomized complete block design (RCBD) with four replications. Data collection was centred on root length, plant height, number of leaves, leaf area,
\end{abstract}

${ }^{1}$ Department of Agronomy, University of llorin, Nigeria dry mass, final yield, chlorophyll content of leaves, crude protein and crude fat contents. From this work, it was found that $200 \mathrm{mM} \mathrm{NaCl}$ decreased the final yield by $51 \%$ in ITIOK-298-15, 73\% in IFE BROWN and $100 \%$ in SAMPEA-11 compared to the control. Furthermore, $100 \mathrm{mM} \mathrm{NaCl}$ reduced crude protein contents of the leaves by $6 \%$ in ITIOK$298-15,10 \%$ in IFE BROWN and $17 \%$ in SAMPEA-11 compared to the control. From the above results, it was found that ITIOK-298-15 was the most tolerant cultivar while SAMPEA-11 was the most susceptible cultivar to salinity stress. It is, therefore, recommended (subject to further confirmation) that ITIOK-298-15 cultivar, which is the most promising cultivar of the three cultivars experimented, be used in cowpea production in saline environments of the Southern Guinea savannah ecological areas of Nigeria.

Keywords: salinity stress; cowpea cultivars; cowpea yield; cowpea quality. 


\section{INTRODUCTION}

Rapid population growth all over the world increases demand for food beyond what salinity-free soils can cater for. This has heightened the importance of finding solutions to salt affected soils to boost food production. Diverse methods used to alleviate the problems of soil salinity are physical removal, flushing and leaching but these methods are characterized by high mechanical and financial costs. Moreover, flushing and leaching of excess salt require a considerably large amount of fresh quality water which is in fact unavailable. Hence, alternative measures to reduce the problems to give room for optimum crop production in the affected areas are highly needed.

One of the best approaches to deal with salinity stress is the development or selection of salt tolerant crop varieties because obtaining salinity-tolerant cultivars cheaper and easier for poor farmers compared to leaching of salt from the soil surface etc. This leads to maximization of efficiency and better utilization of resources.

Salinity affects various aspects of plant growth from mild osmotic effects which are not easily detected, reduction in shoot and root growth that are more obvious and on the other extreme, chlorosis, necrosis and even senescence of young and old leaves (Munns, 2002). Salinity stress is, therefore, detrimental to morphology, physiology and biochemistry of plants. It has been shown over years that decline in growth occurs in crops grown under saline conditions. However, the degree of reduction was shown to be dependent on other factors such as the level of salt, environmental conditions, the type of plants and the stages of growth. Other environmental factors such as temperature, radiation, humidity, air pollution as well as water availability intensify the effects of salinity stress on crops (Shannon et al., 1994).

Exposure of plants to salinity stress results in an ionic phase where higher levels of salinity lead to excessive accumulation of salts in plant tissue causing ion toxicity. This occurs when plants are exposed to high levels of salinity over a long period of time. Excessive sodium at the root surface disrupts plant potassium nutrition. Due to similarities in the nature of $\mathrm{Na}^{+}$and $\mathrm{K}^{+}$, saline conditions favour the uptake of $\mathrm{Na}^{+}$over $\mathrm{K}^{+}$. Since the former has an inhibitory effect on uptake of the latter, this manifests as potassium deficiency inevitably leading to inhibition of growth.

There is, therefore, need for using salt tolerant cultivars of cowpea to avoid the above highlighted problems and enjoy higher yield with less strenuous efforts. Based on this premise, this experiment was conducted to identify and select the most tolerant cowpea cultivars to salinity stress for propagation in saline areas in southern guinea savannah ecological zone of Nigeria. 


\section{MATERIAL AND METHODS}

\section{Experimental site}

This research was carried out in the glass house of the Faculty of Agriculture, University of Ilorin, Nigeria. The university is located in the southern Guinea Savannah zone of Nigeria.

\section{Plant materials, treatments and experimental design}

The plant materials used in this experiment were three cowpea cultivars (ITIOK-298-15, IFE BROWN and SAMPEA 11) obtained from the Plant Breeding Unit of the Department of Agronomy, Faculty of Agriculture, University of Ilorin, Nigeria. The source of salinity stress was sodium chloride $(\mathrm{NaCl})$ in four different concentrations. The concentrations were $0 \mathrm{mM}$ (the control), $50 \mathrm{mM}, 100 \mathrm{mM}$ and $200 \mathrm{mM}$. Each concentration represented a treatment in the experiment. For each cultivar, separate experiment was conducted. The lay out of the experiments was randomized complete block design (RCBD) with four replications.

\section{Crop husbandry}

\section{and salinity treatment}

For each experiment (each cultivar), four seeds were sown per pot each pot. Each pot is represented by a 7- liter plastic bucket. Each pot contains $5 \mathrm{~kg}$ of air dried sandy-loamy soil. After germination and seedling establishment, the seedlings were thinned to two stands per pot to ease data collection.

Weeds were removed by hand pulling. Lambda cyhalothrin at $300 \mathrm{ml}$ per hectare was used in controlling insect pests. The frequency of application was according to pest incidence to keep the crops off disturbance.
At eighth week after planting, salinity stress was imposed on the plants for two weeks after which normalcy.

\section{Data collection}

\section{Morphological parameters and grain yield}

At maturity, number of leaves per plant were counted and recorded. Also, plant height was measured from the base of the stem just above the ground to the tip of topmost leaf using a measuring tape. Leaf area was determined by multiplying the leaf length by the broadest width and multiplying the result by an established constant for soybean leaf area. At harvest, the root length was measured using a measuring tape after uprooting the plant in a destructive sampling technique. Subsequently, the root was severed from the rest of the plant parts and oven-dried until a constant weight was achieved.

The mass of the oven-dried root was then measured with a balance and recorded. Finally, the pods were harvested and the grains were separated from the pods to determine the mass of the seeds only. The mass of clean grains was then measured using a balance. The value got was recorded as grain yield per plant.

Physiological and biochemical components data were determined as follows:

\section{Leaf Chlorophyll content}

This was measured using a spectrophotometer after forming a homogeneous mixture of $1 \mathrm{~g}$ of leaf sample and $15 \mathrm{ml}$ of ethanol.

\section{Leaf Crude protein content}

The method of extraction of AOAC (1984) was used in determining leaf crude protein. For each treatment, $1 \mathrm{~g}$ of leaf sample was weighed into a digestion flask. Ten gram of $\mathrm{K}_{2} \mathrm{SO}_{4}, 0.7 \mathrm{~g}$ mercuric oxide and $20 \mathrm{~cm}^{3}$ of concentrated $\mathrm{H}_{2} \mathrm{SO}_{4}$ were added to the sample in an inclined digestion flask. The flask which was 


\section{SALINITY STRESS TOLERANCE OF THREE COWPEA CULTIVARS}

inclined was heated gently for half an hour until frothing subsided and boiled until the solution became clear. When the frothing was in excess, a small amount of paraffin wax was added. On boiling, $90 \mathrm{ml}$ of distilled water was added and mixed. A small piece of pumice was added to prevent bumping. Then $80 \mathrm{ml}$ of $2 \mathrm{M}$ sodium hydroxide solution was added while filling the flask so that two layers could form. The condenser unit was then connected to the inclined flask. Distilled ammonia collected in $50 \mathrm{ml}$ boric acid /methyl red indicator mixed with $50 \mathrm{ml}$ of the distillate was titrated against $0.1 \mathrm{M}$ hydrochloric acid solution. The percentage nitrogen content was then calculated as follows:

$$
\% N=\frac{[(\text { Volume of acid } \times \text { Molarity of standard acid }) \times 0.014 \times 100]}{\text { Mass of sample }(g)} \times 100
$$

\section{Leaf Crude fat content}

Leaf crude fat content was determined using soxhlet extraction method (AOAC, 1984). For each treatment, $2 \mathrm{~g}$ of leaf sample was weighed into a soxhlet extraction thimble and plugged with cotton wool to avoid sample loss. The thimble was transferred into a soxhlet extractor and sufficient amount of petroleum ether was added. The sample was then siphoned into the receiving flask of known mass. Ether was added to cover the thimble completely and the flask was placed with the extractor on the electric heating mantle. The reflux condenser was heated gently for 3 hours and then allowed to cool down for $10 \mathrm{~min}$. Recovered solvent was transferred into an oven with temperature of $100^{\circ} \mathrm{C}$ and was left for an hour. The recovered solvent was then cooled down in a desiccator and weighed. The amount of oil produced was then calculated and expressed as percentage of original sample as follows:

$$
\% \text { Fat }=\frac{\text { Mass loss of sample (extracted fat) }}{\text { Mass of sample }(\mathrm{g})} \times 100
$$

\section{Statistical analysis}

All the data collected were analysed using analysis of variance (ANOVA) and significant means were separated using Duncan Multiple Range Test (DMRT) at $p<0.05$ with the aid of IBM SPSS version 20 package.

\section{RESULTS AND DISCUSSION}

\section{Effect of salinity stress on root length of three cowpea cultivars}

For ITIOK-298-15, the longest roots $(21.25 \mathrm{~cm})$ were found in the control. This was followed by plants treated with $50 \mathrm{mM}$ and $200 \mathrm{mM} \mathrm{NaCl}$ which were $18.50 \mathrm{~cm}$ long with percentage reduction of $12.75 \%$. Finally, the shortest roots $(17 \mathrm{~cm})$ were obtained from plants treated with $100 \mathrm{mM} \mathrm{NaCl}$ with $12.94 \%$ reduction (Table 1).

As for IFE BROWN, the longest roots $(18 \mathrm{~cm})$ were still from the control. This was followed by roots of plants treated with $100 \mathrm{mM} \mathrm{NaCl}$ which were $16.75 \mathrm{~cm}$ long with $6.94 \%$ reduction compared to the control. However, the shortest roots $(13.5 \mathrm{~cm})$ were from plants treated with $200 \mathrm{mM} \mathrm{NaCl}$ and the percentage reduction was $25 \%$ (Table 1 ). 


\section{KAREEM, A.I. MUSA}

SAMPEA-11 was seriously affected by salinity stress. The shortest roots $(4.38 \mathrm{~cm})$ were from $200 \mathrm{mM} \mathrm{NaCl}$ treated plants resulting in $73.05 \%$ reduction. The least affected roots $(15.25 \mathrm{~cm})$ were from plants treated with $50 \mathrm{mM} \mathrm{NaCl}$ with the resultant reduction of $6.15 \%$ when compared to the control $(16.25 \mathrm{~cm})$ : $50 \mathrm{mM} \mathrm{NaCl}$ resulted in a $6.15 \%$ decrease in root length, when compared with the control (Table 1).

Table 1 - Effect of salinity stress on cowpea root length

\begin{tabular}{|c|c|c|c|}
\hline Treatment & $\begin{array}{c}\text { Root length }(\mathrm{cm}) \\
\text { ITIOK-298-15 }\end{array}$ & IFE BROWN & SAMPEA-11 \\
\hline $0 \mathrm{mM} \mathrm{NaCl}$ & $21.25^{\mathrm{a}} \pm 4.35$ & $18.00^{\mathrm{a}} \pm 1.63$ & $16.25^{\mathrm{C}} \pm 0.96$ \\
\hline $50 \mathrm{mM} \mathrm{NaCl}$ & $18.50^{\mathrm{a}} \pm 2.08$ & $16.00^{\mathrm{a}} \pm 6.16$ & $15.25^{C} \pm 2.36$ \\
\hline $100 \mathrm{mM} \mathrm{NaCl}$ & $17.00^{a} \pm 6.48$ & $16.75^{\mathrm{a}} \pm 7.14$ & $11.75^{b} \pm 2.36$ \\
\hline $200 \mathrm{mM} \mathrm{NaCl}$ & $18.50^{a} \pm 1.92$ & $13.5^{a} \pm 6.86$ & $4.38^{a} \pm 0.48$ \\
\hline
\end{tabular}

Means with the same letter (s) in the same column are not significantly different from one another at 0.05 probability level.

\section{Effect of salinity stress on cowpea height}

The tallest plants $(32 \mathrm{~cm})$ in ITIOK-298-15 were from plants treated with $100 \mathrm{mM} \mathrm{NaCl}$ which was $12.88 \%$ taller than the control. Plants treated with $50 \mathrm{mM} \mathrm{NaCl}$ had height reduction of $4.94 \%$ when compared to the control (Table 2).

For IFE BROWN, the tallest plants $(26.13 \mathrm{~cm})$ were from the control and they were $18.67 \%$ and $40.18 \%$ taller than those treated with $50 \mathrm{mM}$ and $200 \mathrm{mM}$ respectively. This was followed by plants treated with $100 \mathrm{mM} \mathrm{NaCl}(22.75 \mathrm{~cm})$ which was only $12.82 \%$ shorter than the control (Table 2).

The result for SAMPEA-11 showed that the control had the tallest plants $(26.13 \mathrm{~cm})$ and they were $8.15 \%$ taller than the plants treated with $50 \mathrm{mM} \mathrm{NaCl}$. Plants treated with $200 \mathrm{mM} \mathrm{NaCl}$ produced the shortest plants $(16.25 \mathrm{~cm})$ which were $37.81 \%$ shorter than the control (Table 2).

\section{Effect of salinity stress on cowpea number of leaves}

The highest number of leaves (20.00) for ITIOK-298-15 cultivar was from the control. Plants treated with $50 \mathrm{mM} \mathrm{NaCl}$ showed a reduction of $15.94 \%$ when compared to the control. Treatment with $100 \mathrm{mM} \mathrm{NaCl}$ and $200 \mathrm{mM} \mathrm{NaCl}$ decreased the number of leaves by $12.12 \%$ and $32.5 \%$ respectively compared to the control (Table 3).

Similar results were obtained for IFE BROWN cultivar. The highest number of leaves (24.00) was obtained from the control while $50 \mathrm{mM} \mathrm{NaCl}, 100 \mathrm{mM} \mathrm{NaCl}$ and $200 \mathrm{mM} \mathrm{NaCl}$ resulted in $8.92 \%$, $16.25 \%$ and $61.26 \%$ decrease in the number of leaves respectively when compared to the control (Table 3).

For SAMPEA-1, the highest number of leaves (20.00) was equally obtained from the control. The lowest number of leaves (9.00) was from plants treated with $200 \mathrm{mM} \mathrm{NaCl}$ with 


\section{SALINITY STRESS TOLERANCE OF THREE COWPEA CULTIVARS}

$53.47 \%$ reduction when compared with the control. $50 \mathrm{mM} \mathrm{NaCl}$ and $100 \mathrm{mM} \mathrm{NaCl}$ reduced the number of leaves by $10.71 \%$ and $20.17 \%$ respectively compared to the control (Table 3).

Table 2 - Effect of salinity stress on cowpea height

\begin{tabular}{|c|c|c|c|}
\hline Treatment & $\begin{array}{c}\text { Plant height }(\mathrm{cm}) \\
\text { ITIOK-298-15 }\end{array}$ & IFE BROWN & SAMPEA-11 \\
\hline OmM NaCl & $27.88^{\mathrm{a}} \pm 3.20$ & $26.13^{b} \pm 5.39$ & $26.13^{b} \pm 7.11$ \\
\hline $50 \mathrm{mM} \mathrm{NaCl}$ & $26.50^{a} \pm 2.68$ & $21.25^{\mathrm{ab}} \pm 4.99$ & $24.00^{\mathrm{ab}} \pm 3.65$ \\
\hline $100 \mathrm{mM} \mathrm{NaCl}$ & $32.00^{a} \pm 5.73$ & $22.75^{\mathrm{b}} \pm 1.82$ & $19.88^{\mathrm{a}} \pm 0.84$ \\
\hline $200 \mathrm{mM} \mathrm{NaCl}$ & $27.50^{a} \pm 9.47$ & $15.63^{a} \pm 3.64$ & $16.25^{a} \pm 5.17$ \\
\hline
\end{tabular}

Means with the same letter (s) in the same column are not significantly different from one another at 0.05 probability level.

Table 3 - Effect of salinity stress on cowpea number of leaves

\begin{tabular}{lcll}
\hline \multirow{2}{*}{ Treatment } & \begin{tabular}{c} 
Number of leaves \\
\cline { 2 - 3 }
\end{tabular} & IFE BROWN & \multirow{2}{*}{ SAMPEA-11 } \\
\hline $0 \mathrm{mM} \mathrm{NaCl}$ & $20.00^{\mathrm{b}} \pm 1.89$ & $24.00^{\mathrm{b}} \pm 3.75$ & $20.00^{\mathrm{c}} \pm 2.56$ \\
\hline $50 \mathrm{mM} \mathrm{NaCl}$ & $17.00^{\mathrm{ab}} \pm 3.03$ & $22.00^{\mathrm{b}} \pm 1.94$ & $18.00^{\mathrm{bc}} \pm 2.18$ \\
\hline $100 \mathrm{mM} \mathrm{NaCl}$ & $17.00^{\mathrm{ab}} \pm 1.71$ & $20.00^{\mathrm{b}} \pm 1.00$ & $16.00^{\mathrm{b}} \pm 2.32$ \\
\hline $200 \mathrm{mM} \mathrm{NaCl}$ & $13.00^{\mathrm{a}} \pm 5.63$ & $9.00^{\mathrm{a}} \pm 3.48$ & $9.00^{\mathrm{a}} \pm 1.71$ \\
\hline
\end{tabular}

Means with the same letter (s) in the same column are not significantly different from one another at 0.05 probability level.

\section{Effect of salinity stress on cowpea leaf area}

The leaves of plants treated with $50 \mathrm{mM} \mathrm{NaCl}$ were larger than the control in the IFE BROWN and SAMPEA-11 cultivars.

In ITIOK-298-15, the largest leaves $\left(31.84 \mathrm{~cm}^{2}\right)$ were from the control followed by plants treated with $100 \mathrm{mM} \mathrm{NaCl}$ whose plant leaves had just $7.94 \%$ area reduction compared to the control. Plants from $50 \mathrm{mM} \mathrm{NaCl}$ and $200 \mathrm{mM} \mathrm{NaCl}$ produced leaves whose areas were $35.57 \%$ and $37.20 \%$ respectively below the control (Table 4).

Results from IFE BROWN showed that the largest leaves $\left(33.12 \mathrm{~cm}^{2}\right)$ were from plants treated with $50 \mathrm{mM} \mathrm{NaCl}$ were $4.02 \%$ better than the control $\left(31.84 \mathrm{~cm}^{2}\right)$. However, plants treated with $100 \mathrm{mM}$ $\mathrm{NaCl}$ and $200 \mathrm{mM}$ were respectively $4.21 \%$ and $40.95 \%$ below the control (Table 4).

In SAMPEA-11, the leaf surface area of plants treated with $50 \mathrm{mM}$ $\mathrm{NaCl}$ were $49.88 \%$ larger than the control $\left(24.46 \mathrm{~cm}^{2}\right)$. Plants treated with $100 \mathrm{mM} \mathrm{NaCl}$ showed a $6.66 \%$ increase in the leaf surface area over the control. The smallest leaves $\left(11.56 \mathrm{~cm}^{2}\right)$ were found in plants treated with $200 \mathrm{mM} \mathrm{NaCl}$ which were $52.74 \%$ smaller than the leaves from the control (Table 4). 
Table 4 - Effect of salinity stress on cowpea leaf area

\begin{tabular}{|c|c|c|c|}
\hline Treatment & $\begin{array}{c}\text { Leaf area }(\mathrm{cm} 2) \\
\text { ITIOK-298-15 } \\
\end{array}$ & IFE BROWN & SAMPEA-11 \\
\hline $0 \mathrm{mM} \mathrm{NaCl}$ & $42.82^{b} \pm 12.89$ & $31.84^{b} \pm 11.36$ & $24.46^{b} \pm 6.28$ \\
\hline $50 \mathrm{mM} \mathrm{NaCl}$ & $27.59^{\mathrm{a}} \pm 7.46$ & $33.12^{b} \pm 8.93$ & $36.66^{\mathrm{C}} \pm 4.11$ \\
\hline $100 \mathrm{mM} \mathrm{NaCl}$ & $29.78^{a} \pm 6.97$ & $30.50^{\mathrm{ab}} \pm 5.73$ & $26.09^{b} \pm 7.65$ \\
\hline $200 \mathrm{mM} \mathrm{NaCl}$ & $26.89^{a} \pm 4.09$ & $18.18^{a} \pm 3.88$ & $11.56^{\mathrm{a}} \pm 2.10$ \\
\hline
\end{tabular}

Means with the same letter (s) in the same column are not significantly different from one another at 0.05 probability level.

\section{Effect of salinity stress on cowpea dry matter production}

Results from ITIOK-298-15 showed that the highest dry matter $(6.70 \mathrm{~g})$ production was from plants treated with $50 \mathrm{mM} \mathrm{NaCl}$ which was $1.2 \%$ heavier than the control. Plants treated with $100 \mathrm{mM} \mathrm{NaCl}$ had $23.94 \%$ dry mater reduction compared to the control. The lowest dry matter was from plants treated with $200 \mathrm{mM} \mathrm{NaCl}$. This amounts to a $30 \%$ dry matter reduction compared to the control (Table 5).

As for IFE BROWN, the highest dry matter $(6.27 \mathrm{~g})$ was from the control while plants treated with $50 \mathrm{mM}, \quad 100 \mathrm{mM}$ and $200 \mathrm{mM}$ had $30.30 \%, 20.96 \%, 33.65 \%$ and $41.63 \%$ dry matter reduction respectively compared to the control (Table 5).

In the same vein, the highest dry matter in SAMPEA-11 was from the control $(6.25 \mathrm{~g})$ and it was $325 \%$ better than plants treated with $200 \mathrm{mM}$ $\mathrm{NaCl}$ which had the lowest dry matter production. Similarly, plants from the control were $12.96 \%$ and $20.96 \%$ respectively better than plants treated with $50 \mathrm{Mm} \mathrm{NaCl}$ and $100 \mathrm{Mm} \mathrm{NaCl}$ in dry matter production (Table 5).

\section{Effect of salinity stress on cowpea grain yield}

The highest grain yield (28.25 g) in ITIOK-298-15 was from the control and was $105.45 \%$ better than the lowest yields recorded from plants treated with $200 \mathrm{mM} \mathrm{NaCl}$. Plants treated with $50 \mathrm{mM} \mathrm{NaCl}$ had $23 \%$ yield reduction compared to the control. Similarly, plants treated with $100 \mathrm{Mm} \mathrm{NaCl}$ had a yield of $33.62 \%$ compared to the control (Table 6).

In IFE BROWN, the highest grain yield (35.50 g) was from the control while the lowest yield was from the plants treated with $200 \mathrm{mM}$ $\mathrm{NaCl}$. The yield reduction between the highest and the lowest was $73.24 \%$ (Table 6).

The grain yields from plants treated with $50 \mathrm{mM}$ and $100 \mathrm{mM} \mathrm{NaCl}$ were reduced in yield by $35.92 \%$ and $54.22 \%$ respectively when compared to the control. The highest yield $(20.75 \mathrm{~g})$ from SAMPEA-11 was from the control and was followed by plants treated with $50 \mathrm{mM} \mathrm{NaCl}$ which were $16.87 \%$ below the control. Plants treated with $100 \mathrm{mM}$ and 200 $\mathrm{mM} \mathrm{NaCl}$ had $44.58 \%$ and $100 \%$ yield reduction respectively compared to the control (Table 6). 
SALINITY STRESS TOLERANCE OF THREE COWPEA CULTIVARS

Table 5 - Effect of salinity stress on cowpea dry matter production

\begin{tabular}{lccl}
\hline \multirow{2}{*}{ Treatment } & Dry mass (g) & IFE BROWN & SAMPEA-11 \\
\cline { 2 - 3 } & ITIOK-298-15 & & \\
\hline $0 \mathrm{mM} \mathrm{NaCl}$ & $6.60^{\mathrm{a}} \pm 1.66$ & $6.27^{\mathrm{c}} \pm 2.65$ & $6.25^{\mathrm{b}} \pm 1.15$ \\
\hline $50 \mathrm{mM} \mathrm{NaCl}$ & $6.70^{\mathrm{a}} \pm 4.69$ & $4.37^{\mathrm{a}} \pm 2.65$ & $5.44^{\mathrm{b}} \pm 2.18$ \\
\hline $100 \mathrm{mM} \mathrm{NaCl}$ & $5.02^{\mathrm{a}} \pm 3.26$ & $4.16^{\mathrm{a}} \pm 1.50$ & $4.94^{\mathrm{b}} \pm 0.86$ \\
\hline $200 \mathrm{mM} \mathrm{NaCl}$ & $4.62^{\mathrm{a}} \pm 1.96$ & $3.66^{\mathrm{a}} \pm 2.06$ & $1.47^{\mathrm{a}} \pm 0.73$ \\
\hline
\end{tabular}

Means with the same letter (s) in the same column are not significantly different from one another at 0.05 probability level.

Table 6 - Effect of salinity stress on cowpea grain yield

\begin{tabular}{llll}
\hline \multirow{2}{*}{ Treatment } & Final yield per stand (g) & \multirow{2}{*}{ IFE BROWN } & \multirow{2}{*}{ SAMPEA-11 } \\
\cline { 2 - 4 } & ITIOK-298-15 & & \\
\hline $0 \mathrm{mM} \mathrm{NaCl}$ & $28.25^{\mathrm{c}} \pm 5.91$ & $35.50^{\mathrm{c}} \pm 7.55$ & $20.75^{\mathrm{c}} \pm 2.22$ \\
\hline $50 \mathrm{mM} \mathrm{NaCl}$ & $21.75^{\mathrm{b}} \pm 1.71$ & $22.75^{\mathrm{b}} \pm 6.85$ & $17.25^{\mathrm{c}} \pm 3.77$ \\
\hline $100 \mathrm{mM} \mathrm{NaCl}$ & $18.75^{\mathrm{ab}} \pm 2.21$ & $16.25^{\mathrm{ab}} \pm 3.95$ & $11.50^{\mathrm{b}} \pm 3.32$ \\
\hline $200 \mathrm{mM} \mathrm{NaCl}$ & $13.75^{\mathrm{a}} \pm 3.95$ & $9.50^{\mathrm{a}} \pm 7.42$ & $-^{\mathrm{a}}$ \\
\hline
\end{tabular}

Means with the same letter (s) in the same column are not significantly different from one another at 0.05 probability level

Effect of salinity stress on cowpea leaf chlorophyll

The leaf chlorophyll content of ITIOK-298-15 washighest $\left(2.63 \mathrm{mgg}^{-1}\right)$ in the control. This was followed by the plants treated with $50 \mathrm{mM}$ and $200 \mathrm{mM} \mathrm{NaCl}$ and the magnitude of reduction was $0.76 \%$. However, the lowest chlorophyll content was from plants treated with $100 \mathrm{mM} \mathrm{NaCl}$ which was $1.14 \%$ lower than that of the control (Table 7).

For IFE BROWN, the highest chlorophyll content $\left(2.67 \mathrm{mg} \mathrm{g}^{-1}\right)$ was also from the control while the lowest was from the plants treated with $200 \mathrm{mM} \mathrm{NaCl}$. This was $3.75 \%$ lower than the control. For plants treated with $50 \mathrm{mM} \mathrm{NaCl}$ and $100 \mathrm{mM} \mathrm{NaCl}$, the reductions were respectively $1.12 \%$ and $2.23 \%$ compared to the control (Table 7).

The control also produced plants with the highest leaf chlorophyll content $\left(2.65 \mathrm{mg} \mathrm{g}^{-1}\right)$ in SAMPEA-11 while the lowest was still from plants treated with $200 \mathrm{mM} \mathrm{NaCl}$. Treatment with $50 \mathrm{mM}$ and $100 \mathrm{mM} \mathrm{NaCl}$ led to $0.75 \%$ and $2.26 \%$ chlorophyll content reduction respectively compared to the control (Table 7).

\section{Effect of salinity stress on leaf crude protein of three cowpea cultivars}

The leaf crude protein content of ITIOK-298-15 was highest (21.6\%) in the control plants. This result was on the par with plants treated with $200 \mathrm{mM} \mathrm{NaCl}$. Samples of the plants treated with $50 \mathrm{mM} \mathrm{NaCl}$ and $100 \mathrm{mM}$ $\mathrm{NaCl}$ showed a $3.7 \%$ and $6.02 \%$ decrease in crude protein content when compared to the control (Table 8).

As for IFE BROWN, the highest leaf crude protein $(22.8 \%)$ was from the control plants while the lowest was from plants treated with $200 \mathrm{mM}$ 
$\mathrm{NaCl}$. The reduction level was $19.73 \%$ compared to the control. Plants treated with $50 \mathrm{mM}$ and $100 \mathrm{mM} \mathrm{NaCl}$ were $5.7 \%$ and $9.64 \%$ respectively lower than the control (Table 8).

In SAMPEA-11, the highest crude protein content $(22.3 \%)$ was also from the control with the lowest from plants treated with $200 \mathrm{mM}$. This was $61.43 \%$ lower than the control. Plants treated with $50 \mathrm{mM} \mathrm{NaCl}$ and $100 \mathrm{mM} \mathrm{NaCl}$ were respectively $4.04 \%$ and $17.04 \%$ lower in leaf crude protein than the control (Table 8).

\section{Effect of salinity stress on cowpea leaf crude fat}

The highest value for leaf crude fat $(6.53 \%)$ was recorded from the control while the lowest which was $34.15 \%$ less than the control was from plants treated with $200 \mathrm{mM} \mathrm{NaCl}$.
Plants treated with $50 \mathrm{mM}$ and $100 \mathrm{mM} \mathrm{NaCl}$ were respectively $5.05 \%$ and $17.3 \%$ below the control (Table 9).

In IFE BROWN, the highest value of crude fat $(6.49 \%)$ was recorded from the control plants. This was followed by plants treated with $50 \mathrm{mM} \mathrm{NaCl}$ which was $3.7 \%$ lower than the control. The lowest crude protein content was found in plants treated with $200 \mathrm{mM}$ and it resulted in 19.88\% reduction (Table 9 ).

Contrary to the trend of results for crude fat content in this work, the highest crude fat content $(7.82 \%)$ in SAMPEA-11 was found in in plants treated with $100 \mathrm{mM}$. This was $3.99 \%$ higher than the control. The lowest crude protein content was still from plants treated with $200 \mathrm{mM} \mathrm{NaCl}$ and was $27.74 \%$ lower than the control (Table 9).

Table 7 - Effect of salinity stress on cowpea leaf chlorophyll

\begin{tabular}{lccc}
\hline \multirow{2}{*}{ Treatment } & $\begin{array}{c}\text { Total chlorophyll content } \\
\text { (mg g-1 fresh weight) }\end{array}$ & IFE BROWN & SAMPEA-11 \\
\cline { 2 - 4 } & $\begin{array}{l}\text { ITIOK-298-15 } \\
2.63^{\mathrm{a}} \pm 0.02\end{array}$ & $2.67^{\mathrm{d}} \pm 0.01$ & $2.65^{\mathrm{b}} \pm 0.02$ \\
\hline $0 \mathrm{mM} \mathrm{NaCl}$ & $2.61^{\mathrm{a}} \pm 0.04$ & $2.64^{\mathrm{c}} \pm 0.01$ & $2.63^{\mathrm{b}} \pm 0.02$ \\
\hline $50 \mathrm{mM} \mathrm{NaCl}$ & $2.60^{\mathrm{a}} \pm 0.02$ & $2.61^{\mathrm{b}} \pm 0.02$ & $2.59^{\mathrm{a}} \pm 0.01$ \\
\hline $100 \mathrm{mM} \mathrm{NaCl}$ & $2.61^{\mathrm{a}} \pm 0.01$ & $2.57^{\mathrm{a}} \pm 0.03$ & $2.59^{\mathrm{a}} \pm 0.03$ \\
\hline $200 \mathrm{mM} \mathrm{NaCl}$ & &
\end{tabular}

Means with the same letter (s) in the same column are not significantly different from one another at 0.05 probability level

Table 8 - Effect of salinity stress on cowpea leaf crude protein

\begin{tabular}{lccl}
\hline \multirow{2}{*}{ Treatment } & $\begin{array}{c}\text { Crude protein (\%) } \\
\text { ITIOK-298-15 }\end{array}$ & IFE BROWN & SAMPEA-11 \\
\hline $0 \mathrm{mM} \mathrm{NaCl}$ & $21.6^{\mathrm{a}} \pm 0.6$ & $22.8^{\mathrm{d}} \pm 0.6$ & $22.3^{\mathrm{c}} \pm 0.4$ \\
\hline $50 \mathrm{mM} \mathrm{NaCl}$ & $20.8^{\mathrm{a}} \pm 0.3$ & $21.5^{\mathrm{c}} \pm 0.4$ & $21.4^{\mathrm{b}} \pm 0.2$ \\
\hline $100 \mathrm{mM} \mathrm{NaCl}$ & $20.3^{\mathrm{a}} \pm 1.2$ & $20.6^{\mathrm{b}} \pm 0.3$ & $18.5^{\mathrm{a}} \pm 0.6$ \\
\hline $200 \mathrm{mM} \mathrm{NaCl}$ & $21.6^{\mathrm{a}} \pm 0.2$ & $18.3^{\mathrm{a}} \pm 1.2$ & $8.6^{\mathrm{a}} \pm 0.2$ \\
\hline
\end{tabular}

Means with the same letter (s) in the same column are not significantly different from one another at 0.05 probability level. 
SALINITY STRESS TOLERANCE OF THREE COWPEA CULTIVARS

Table 9 - Effect of salinity stress on cowpea leaf crude fat

\begin{tabular}{|c|c|c|c|}
\hline Treatment & $\begin{array}{c}\text { Crude protein (\%) } \\
\text { ITIOK-298-15 }\end{array}$ & IFE BROWN & SAMPEA-11 \\
\hline $0 \mathrm{mM} \mathrm{NaCl}$ & $6.53^{\mathrm{d}} \pm 0.14$ & $6.49^{d} \pm 0.08$ & $7.52^{d} \pm 0.16$ \\
\hline $50 \mathrm{mM} \mathrm{NaCl}$ & $6.20^{C} \pm 0.11$ & $6.25^{\mathrm{C}} \pm 0.13$ & $7.32^{\mathrm{C}} \pm 0.03$ \\
\hline $100 \mathrm{mM} \mathrm{NaCl}$ & $5.40^{b} \pm 0.37$ & $5.70^{b} \pm 0.11$ & $7.82^{b} \pm 0.45$ \\
\hline $200 \mathrm{mM} \mathrm{NaCl}$ & $4.30^{a} \pm 0.28$ & $5.2^{a} \pm 0.27$ & $5.65^{a} \pm 0.38$ \\
\hline
\end{tabular}

Means with the same letter (s) in the same column are not significantly different from one another at 0.05 probability level

\section{DISCUSSION}

All cowpea roots in this experiment responded negatively to salinity stress with the exception of ITIOK-298-15. This reduction in root length could be attributed to inability of the roots to absorb water because of being in hypertonic solution. Though this might not have affected cell division, but cell enlargement and elongation which lead to increase in root length are affected. Furthermore, the reduction could be due to reduced rate of cell production and consequently growth (Zadeh and Naeini, 2007). However, the roots of ITIOK-298-15 were less affected despite the severity of the salinity stress. This implies that ITIOK-298-15 cultivar was tolerant to the imposed stress. This was manifested in its better vegetative growth compared to other cultivars.

Plant height of all cultivars was adversely affected by salt stress except for ITIOK-268-15 cultivars. Reduced plant height caused by salinity stress might be caused by reduced cell division occasioned by osmotic stress from saline soil solution. It might equally be the result of inability of getting sufficient water and nutrient needed for cell elongation and enlargement as a result of physiological dryness experienced by the plants. This might have had consequential effect on photosynthate production because water and some nutrients like potassium and chlorine areneededforsuccessfulphotosynthetic activities. With less photosynthate production, translocation to the growing areas becomes a great difficulty and, therefore, growth is affected. This was manifested in reduced plant height found in this work.

However, ITIOK-298-15 cultivar still displayed its tolerance to the imposed salinity stress. This might be attributed to cell membrane stability and lower osmotic potential of the cells which led to influx of water from the surrounding soil into the roots for biochemical and physiological use. In addition to that, it could equally be a result of the ability of the cultivar to sequester salt in its body. Therefore, the plants grew without being affected.

There was an inverse relationship between salinity and number of leaves as well as leaf area This implies that increase in the 


\section{KAREEM, A.I. MUSA}

concentration of salts led to a decrease in the number of leaves and leaf area. However, an interesting increase in the leaf area for SAMPEA-11 was recorded at $50 \mathrm{mM}$ before it followed the established trend in this work was followed. This might be because plants faced with the problem of salinity experienced a change in cell wall properties, leaf turgor and photosynthetic rates which then led to reduction in leaf total area. In the same vein, reduction in leaf number and leaf area could have resulted from reduced turgor or reduction in extensibility of cell walls (Neumann, 1993). The problem could still be due to water stress in the short run and ion toxicity in the long run (Yeo et al., 1991). This reduction in leaf area can be seen as an avoidance mechanism which occurs so as to reduce water loss by transpiration This effect is also capable of limiting the accumulation of the salt ions in the shoot by favouring the retention of toxic ions in the roots (Munns and Tester, 2008)

From this study, dry mass was observed to have decreased with salinity in all tested cultivars. This could have resulted from reduction in the number and size of leaves, senescence and total abscission which reduced photsynthate production and consequently the dry matter accumulation. Furthermore, it might be that there was build-up of chlorine in the leaves of salt stressed plants and that triggered the synthesis of some forms of carboxylic acids which are converted to ethylene( a hormone) which triggered abscission in plants
(Dodd, 2005). Finally, it should be noted that senescence may occur prior to accumulation of toxic ions and, therefore, osmotic phase is characterized by accumulation of abscisic acid (ABA) and a decrease in indole-3-acetic acid (IAA) (Albacete et al., 2008 and Ghanem et al., 2008).

Final yield for all cultivars reduced with increasing salinity. The combined effects of reductions in root size, number of leaves and leaf area led to a drastic reduction in the production and distribution of photosynthate which ultimately caused a reduction the final yield.

Total chlorophyll content was recorded to have decreased with increasing salinity. This decrease could be as a result of salt induced weakening of protein-pigment lipid complex and increased chlorophyllase activity (Ambede et al., 2012). The reduction in chlorophyll content together with reduced potassium uptake which results in $\mathrm{K} / \mathrm{Na}$ antagonism resulted in impaired photosynthesis which consequently led to low yield. The seeming tolerance of ITIOK-298-15 to salinity with respect to chlorophyll content might explain why it performed better vegetatively and reproductively.

The results also indicated a decrease in crude protein with increasing salinity. This might have resulted from decreased synthesis of protein as well as increased activities of protein hydrolysing enzymes which led to accumulation of amino acids at the expense of protein (Pessarakli and Tucker, 1988). Furthermore, it is well 
known that higher ratio of $\mathrm{Na}^{+}$to $\mathrm{K}^{+}$ and accumulation of salts at high salinity level inactivate enzymes and inhibit synthesis of protein. Finally, reduction in protein content might be attributed to low nitrate reduction activity (NR) which could have accounted for decline in plant growth.

\section{CONCLUSION}

It was found from this work that ITIOK-298-15 was the most tolerant cultivar to salinity stress while SAMPEA-11 was the most susceptible.

It is, therefore, recommended (subject to further confirmation) that ITIOK-298-15 which is the most promising cultivar of the three cultivars experimented be used in cowpea production in saline environments of the Southern Guinea savannah ecological areas of Nigeria.

\section{REFERENCES}

Albacete, A., Ghanem, M. E., MartínezAndújar, C., Acosta, M., SánchezBravo, J., Martínez, V., ... \& PérezAlfocea, F. (2008). Hormonal changes in relation to biomass partitioning and shoot growth impairment in salinized tomato (Solanum lycopersicum L.) plants. J.Exp.Bot., 59(15): 4119-4131, DOI: 10.1093/jxb/ern251

Ambede, J. G., Netondo, G. W., Mwai, G. N. \& Musyimi, D. M. (2012). $\mathrm{NaCl}$ salinity affects germination, growth, physiology, and biochemistry of bambara groundnut. Braz. J.Plant Physiol., 24(3): 151-160, DOI: 10.1590/S1677-04202012000300 002
AOAC (1984). Official method of the analysis of the association of the official analytical chemist. $12^{\text {th }}$ Edition, Washington DC.

Dodd, I. C. (2005). Root-to-shoot signalling: assessing the roles of 'up'in the up and down world of longdistance signalling in planta. Plant and soil, 274(1-2): 251-270, DOI: 10.1007/s11104-004-0966-0

Ghanem, M.E., Albacete, A., MartínezAndújar, C., Acosta, M., RomeroAranda, R., Dodd, I.C., ... \& PérezAlfocea, F. (2008). Hormonal changes during salinity-induced leaf senescence in tomato (Solanum lycopersicum L.). J.Exp.Bot., 59(11): 3039-3050, DOI: 10.1093/jxb/ern153

Munns, R. (2002). Comparative physiology of salt and water stress. Plant Cell Environ., 25(2): 239-250, DOI: $10.1046 / \mathrm{j} .0016-8025.2001 .008$ 08.x

Munns, R. \& Tester, M. (2008). Mechanisms of salinity tolerance. Annu. Rev. Plant Biol., 59: 651-681, DOI: 10.1146/annurev.arplant.59.03 2607.092911

Neumann, P.M. (1993). Wall extensibility and the growth of salt stressed leaves. In: Interacting Stresses on Plants in a Changing Climate, pp. 603-615, Springer, Berlin, Heidelberg.

Pessarakli, M. \& Tucker, T. C. (1988). Dry matter yield and nitrogen-15 uptake by tomatoes under sodium chloride stress. Soil Sci.Soc.Am.J., 52(3): 698-700, DOI: 10.2136/sssaj 1988.03615995005200030019x

Shannon, M.C., Grieve, C.M. \& François, L.E. (1994). Whole-plant response to salinity. In: Wilkinson R.E. (Ed.). Plant-environment interactions, New York: Marcel Dekker, pp.199-244.

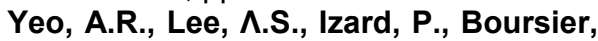
P.J. \& Flowers, T.J. (1991). Shortand long-term effects of salinity on leaf growth in rice (Oryza sativa L.). J.Exp.Bot., 42(7): 881-889, DOI: 10.1093/jxb/42.7.881 


\section{KAREEM, A.I. MUSA}

Zadeh, H.M. \& Naeni, M.B. (2007). Effects of salinity stress on the morphology and yield of two cultivars of canola (Brassica napus L.). J.Agron., 6(3): 409-414, DOI: 10.3923/ja.2007.409.414. 